Article

\title{
Bio-Minerals Combined with Bacillus cereus for Enhancing the Nitrogen Removal Efficiency under Aerobic Conditions
}

\author{
Hyunhee Seo and Yul Roh * \\ Department of Earth and Environmental Sciences, Chonnam National University, Gwangju 61186, Korea; \\ seo_hyunhee@hanmail.net \\ * Correspondence: rohy@jnu.ac.kr; Tel.: +82-62-530-3458
}

Received: 29 May 2018; Accepted: 12 June 2018; Published: 15 June 2018

\begin{abstract}
Nitrogen compounds such as nitrate, nitrite, and ammonium are among the prolonged contaminants in surface water and groundwater worldwide. In this study, we evaluated nitrogen removal efficiency using the combination of biologically synthesized Pd-FeS and Bacillus cereus in comparison between two batch reactors, one with a single nitrate $\left(\mathrm{NO}_{3}{ }^{-}-\mathrm{N}\right)$ and the other with a mixed nitrogen $\left(\mathrm{NO}_{3}{ }^{-}-\mathrm{N}+\mathrm{NO}_{2}{ }^{-}-\mathrm{N}+\mathrm{NH}_{4}{ }^{-}-\mathrm{N}\right)$ under aerobic conditions. The removal efficiency of $\mathrm{NO}_{3}{ }^{-}-\mathrm{N}$ by bio-Pd-FeS + Bacillus cereus in a single nitrate reactor showed $100 \%$ with a low production (ca. $10 \%$ ) of $\mathrm{NO}_{2}{ }^{-}-\mathrm{N}$ and $\mathrm{NH}_{4}{ }^{+}-\mathrm{N}$ for 5 days and this combination was three-fold more effective than a single application of bio-Pd-FeS and Bacillus cereus respectively. Also, bio-Pd-FeS + Bacillus cereus in the mixed nitrogen $\left(\mathrm{NO}_{3}{ }^{-}-\mathrm{N}+\mathrm{NO}_{2}{ }^{-}-\mathrm{N}+\mathrm{NH}_{4}{ }^{+}-\mathrm{N}\right)$ removed $95 \% \mathrm{NO}_{3}{ }^{-}-\mathrm{N}, 20 \% \mathrm{NO}_{2}{ }^{-}-\mathrm{N}$, and $35 \% \mathrm{NH}_{4}{ }^{+}-\mathrm{N}$, respectively. Since iron and sulfur-based bio-minerals could be reusable in a reducing condition of in-situ and in an oxygen-limited closed condition of ex-situ applications, the results suggested that the combination should get more attention for an efficient eco-friendly sustainable bioremediation technology.
\end{abstract}

Keywords: bio-Pd-FeS; bio-minerals; Bacillus cereus; aerobic nitrogen removal; bio-denitrification

\section{Introduction}

Nitrogen is an essential element but excessive nitrogen compounds such as nitrate, nitrite, and ammonium are contaminants in soil and groundwater. Diverse industrial uses such as artificial fertilizers and improper discharge of wastewater have been urged to limit the access of clean, safe, and healthy water [1]. In most countries including South Korea, the maximum contaminant level (MCL) for nitrate-nitrogen in public drinking water is $10 \mathrm{mg} / \mathrm{L}(11 \mathrm{mg} / \mathrm{L}, \mathrm{WHO}) . \mathrm{MCLs}$ for nitrite-nitrogen are $0.5 \mathrm{mg} / \mathrm{L}$ in EU, $1 \mathrm{mg} / \mathrm{L}$ in US-EPA and $0.9 \mathrm{mg} / \mathrm{L}$ in WHO [2]. Also, a guideline value for ammonium in drinking water has been set to $0.5 \mathrm{mg} / \mathrm{L}$ in EU. The Ministry of Environment of South Korea has monitored contamination levels of nitrite and ammonium in groundwater to regulate guidelines. Accordingly, nitrate, nitrite, and ammonium-contaminated water must be treated to meet applicable regulations.

Nitrogen removal technology has been adopted and include reverse osmosis, electrodialysis, ion exchange, combined ion exchange and membrane bioreactor, nanofiltration, and biological treatment [3]. Regardless of the technical efficiency and specific capacity of each, concerns still remain in terms of toxicity, byproducts, and costs on operating equipment and labor. It is important to develop optimized alternatives to minimize the use of energy, chemical, and capital-intensive technology. Numerous studies have focused on biotic denitrification using different metabolic types of bacteria such as autotrophs and heterotrophs under aerobic and anaerobic conditions [4-6]. In particular, 
Bacillus strains showed the capability of simultaneous aerobic nitrification and denitrification as a one-step nitrogen removal process [7]. On the other hand, inorganic denitrification using metallic and bimetallic substances such as $\mathrm{Fe}^{0}, \mathrm{Fe}^{2+}, \mathrm{Cu}^{2+}$, catalyzed with $\mathrm{Pd} / \mathrm{Pt}$ and/or hydrogen has been tested and proven to be effective [8-15]. Above all, iron-based minerals, such as $\mathrm{Fe}^{0}, \mathrm{Fe}^{2+}$ and $\mathrm{Fe}^{3+}$ containing minerals are the most commonly used. Recently, iron sulfide has been used as an alternative to nitrogen removal and most iron sulfide has been tested in anoxic environments [16-18]. Compared to chemo-FeS in the nitrogen removal, biogenic FeS have not been extensively studied. There might be some demand to evaluate the nitrogen removal efficiency of the combination of bacteria and biologically synthesized bio-minerals which not only improve the nitrogen removal efficiency, but also minimize the adverse effects such as sharp $\mathrm{pH}$ decreases and toxicity on the ecosystem. A few combination cases of microorganisms and inorganic materials, for instance, Fe supported bacteria for denitrification have been studied as a promising potential $[16,18,19]$. Bio-FeS is expected to act as an electron donor and absorbent under an anaerobic condition during removal of heavy metals [20]. It is therefore necessary to examine whether bio-FeS can improve the nitrogen removal efficiency under an aerobic condition with or without denitrifying aerobic bacteria as an electron donor and/or absorbent. In this study, we examined the aerobic nitrogen removal efficiency using biologically synthesized minerals, bio-FeS and bio-Pd-FeS in the presence or absence of Bacillus cereus strain 146 in single nitrate reactors and in mixed nitrogen reactors under aerobic conditions.

\section{Materials and Methods}

\subsection{Source of Microorganisms for Nitrogen Removal}

Bacillus cereus strain 146 (BC) was isolated from a freshwater stream in Ahnyang, South Korea and purchased from Korea Environmental Microorganisms Bank, South Korea. The characteristics of the strain 146 was known as highly effective to remove nitrate under an aerobic condition. In particular, this strain has been reported to be capable of utilizing nitrate as an electron acceptor under insufficient oxygen conditions [21,22]. To cultivate Bacillus cereus strain 146 (BC), the chemical composition of the microbial growth medium was prepared (Table 1$)$. The medium was autoclaved $\left(1.241\right.$ bar at $\left.121{ }^{\circ} \mathrm{C}\right)$ for $20 \mathrm{~min}$. Unfrozen Bacillus cereus strain 146 was activated in the growth medium with $10 \mathrm{mM}$ of glucose for 1 month in a shaker with $150 \mathrm{rpm}$ at $25^{\circ} \mathrm{C}$.

Table 1. The ingredients of growth medium.

\begin{tabular}{cc}
\hline Ingredients & $(\mathbf{g} / \mathbf{L})$ \\
\hline $\mathrm{NaHCO}_{3}$ & 0.3 \\
$\mathrm{CaCl}_{2} \cdot 2 \mathrm{H}_{2} \mathrm{O}$ & 0.025 \\
$\mathrm{KH}_{2} \mathrm{PO}_{4}$ & 0.3 \\
$\mathrm{MgCl}_{2} \cdot 6 \mathrm{H}_{2} \mathrm{O}$ & 0.1 \\
$\mathrm{HEPES}\left(\mathrm{C}_{8} \mathrm{H}_{18} \mathrm{~N}_{2} \mathrm{O}_{4} \mathrm{~S}\right)$ & 7.2 \\
\hline Trace minerals & $1 \mathrm{~mL}$ \\
Vitamins & $1 \mathrm{~mL}$
\end{tabular}

Growth medium for Bacillus cereus modified from Shin and Cha [23].

\subsection{Bio-FeS and Bio-Pd-FeS for Nitrogen Removal}

Bio-FeS and bio-Pd-FeS were anaerobically synthesized using chemically precipitated ferric precursors (akaganeite and Pd-akaganeite) and metal reducing bacteria enriched from an acid mine drainage site and intertidal flat sediments, Korea [20]. These bio-minerals were identified as a composite of crystalline and amorphous FeS (Pd-FeS) by XRD and TEM-EDS analyses in the previous report. Prior to the test, the bio-minerals were washed with deionized water (DW) three times, kept and applied as a slurry type. 


\subsection{Batch Reduction Experiments}

Batch experiments were conducted to evaluate the removal efficiencies of Bacillus cereus strain 146 (BC), bio-minerals (bio-FeS; BF and bio-Pd-FeS; BPF), and Bacillus cereus + bio-minerals (BC + BF and $\mathrm{BC}+\mathrm{BPF})$ in a single nitrate $\left(\mathrm{NO}_{3}{ }^{-}-\mathrm{N}\right)$ reactor vs. a mixed nitrogen (nitrate; $\mathrm{NO}_{3}{ }^{-}-\mathrm{N}+$ nitrite; $\mathrm{NO}_{2}{ }^{-}-\mathrm{N}+$ ammonium; $\mathrm{NH}_{4}{ }^{+}-\mathrm{N}$ ) reactor under aerobic conditions. For a single nitrate set, the $125-\mathrm{mL}$ glass reactors were prepared to dissolve $50 \mathrm{mg} / \mathrm{L} \mathrm{NO}_{3}{ }^{-}-\mathrm{N}$ in the medium and capped with sterile rubber stoppers. To prevent from unwanted contamination and to aerate atmosphere in the reactors syringe needles and syringe filters were used. $1 \% \mathrm{v} / \mathrm{v}$ of Bacillus cereus strain 146 cultured for 1 month was inoculated with $10 \mathrm{mM}$ of glucose to $\mathrm{BC}, \mathrm{BC}+\mathrm{BF}$, and $\mathrm{BC}+\mathrm{BPF}$ sets. $1 \mathrm{~mL}$ of slurry type of bio-FeS (BF) and bio-Pd-FeS (BPF) was applied respectively to $\mathrm{BF}, \mathrm{BPF}, \mathrm{BC}+\mathrm{BF}$, and $\mathrm{BC}+\mathrm{BPF}$ sets. All reactors were incubated at $25{ }^{\circ} \mathrm{C}$ in a shaker rotating at $150 \mathrm{rpm}$. For mixed nitrogen sets, all the methods were the same as for the single nitrate sets except for the different composition of nitrogen compounds which were prepared to dissolve $20 \mathrm{mg} / \mathrm{L}$ of $\mathrm{NO}_{3}{ }^{-}-\mathrm{N}, \mathrm{NO}_{2}{ }^{-}-\mathrm{N}$ and $\mathrm{NH}_{4}{ }^{+}-\mathrm{N}$, respectively, in a growth medium.

\subsection{Analytical Methods}

Aliquots were sampled with syringe needles, centrifuged at $3000 \mathrm{rpm}$ for $30 \mathrm{~min}$, and filtered through $0.2-\mu \mathrm{m}$ Whatman nylon syringe filters for measurement of anion and cation concentrations. The concentrations of nitrate, nitrite, and sulfate were analyzed using ion chromatography $(\mathrm{CH}-930$ COMPACT IC FLEX, Metrohm, Switzerland) equipped with an anion column (Metrosep A Supp 5, $250 \times 4 \mathrm{~mm}$ ) and a cation column (IonPac CS12 Analytical, $4 \times 250 \mathrm{~mm}$ ) for the concentration of ammonium at detection limit below $10 \mu \mathrm{g} / \mathrm{L}$. The redox potential (Eh) and $\mathrm{pH}$ were measured using a redox electrode and a $\mathrm{pH}$ electrode connected to a benchtop from DKK-TOA, Tokyo, Japan. The morphological and chemical characteristics of pre and post bio-minerals in the reactors were observed by HR-SEM (SU-70, Hitachi, Japan) using energy dispersive spectroscopy (PV7747/67). For SEM-EDS analysis, the solids from the reactors were centrifuged, washed with DW, and dried. The samples were mounted onto stubs, platinum-coated and imaged under $\mathrm{ZrO} / \mathrm{W}$ Schottky Emission Type and secondary election image resolution (1.0 nm at $15.0 \mathrm{kV}$ and W.D. $4 \mathrm{~mm} 2.5 \mathrm{~nm}$ at $1 \mathrm{kV}$, accelerating voltage range: $0.5-30 \mathrm{kV}$ ). For the mineralogical characteristics of bio-minerals in the reactors, the solids from $\mathrm{BF}+\mathrm{BC}$ and $\mathrm{BPF}+\mathrm{BC}$ reactors were centrifuged, washed with $\mathrm{DW}$ more than three times, air-dried, and analyzed by XRD (PIXcel3D with PREFIX INTERFACE Xenon proportional detector, $5^{\circ}-60^{\circ} ; 2 \theta$; step size; $0.026^{\circ}$, scan step time; $46.66 \mathrm{~s}$, Cu- $\mathrm{K} \alpha$ radiation and diffractometer system; EMPYREAN, PANalytical Ltd, Malvern, United Kingdom. Diffraction patterns were analyzed using X'Pert-HighScore Plus (Version 3.0c, Malvern Panalytical Ltd, Malvern, United Kingdom) program for background determination and peak identification.

The removal of nitrate $\left(R_{\mathrm{NO}_{3}}{ }^{-}\right)$, the production of nitrite $\left(P_{\mathrm{NO}_{2}-}\right)$, and ammonium $\left(P_{\mathrm{NH}_{4}}\right)$ and the nitrogen removal efficiency $\left(R_{\mathrm{N}}\right)$ in single nitrate reactors were calculated using the following equations:

$$
\begin{aligned}
& R_{\mathrm{NO}_{3}{ }^{-}}(\%)=\frac{\left[\mathrm{NO}_{3}{ }^{-}-\mathrm{N}\right]_{i}-\left[\mathrm{NO}_{3}{ }^{-}-\mathrm{N}\right]_{f}}{\left[\mathrm{NO}_{3}{ }^{-}-\mathrm{N}\right]_{i}} \times 100 \\
& P_{\mathrm{NO}_{2}{ }^{-}}(\%)=\frac{\left[\mathrm{NO}_{2}{ }^{-}-\mathrm{N}\right]_{f}}{\left[\mathrm{NO}_{3}{ }^{-}-\mathrm{N}\right]_{i}-\left[\mathrm{NO}_{3}{ }^{-}-\mathrm{N}\right]_{f}} \times 100 \\
& P_{\mathrm{NH}_{4}{ }^{+}}(\%)=\frac{\left[\mathrm{NO}_{4}{ }^{+}-\mathrm{N}\right]_{f}}{\left[\mathrm{NO}_{3}{ }^{-}-\mathrm{N}\right]_{i}-\left[\mathrm{NO}_{3}{ }^{-}-\mathrm{N}\right]_{f}} \times 100 \\
& R_{\mathrm{N}}(\%)=\frac{\left[\mathrm{NO}_{3}{ }^{-}-\mathrm{N}\right]_{i}-\left[\mathrm{NO}_{3}{ }^{-}-\mathrm{N}\right]_{f}-\left[\mathrm{NO}_{2}{ }^{-}-\mathrm{N}\right]_{f}-\left[\mathrm{NH}_{4}{ }^{+}-\mathrm{N}\right]_{f}}{\left[\mathrm{NO}_{3}{ }^{-}-\mathrm{N}\right]_{i}} \times 100
\end{aligned}
$$


Also, the removal of nitrate $\left(R_{\mathrm{NO}_{3}{ }^{-}}\right)$, nitrite $\left(R_{\mathrm{NO}_{2}{ }^{-}}\right)$, and ammonium $\left(R_{\mathrm{NH}_{4}{ }^{+}}\right)$and the nitrogen removal efficiency $\left(R_{\mathrm{N}}\right)$ in mixed nitrogen reactors were calculated using the following equations:

$$
\begin{aligned}
& R_{\mathrm{NO}_{3}-}(\%)=\frac{\left[\mathrm{NO}_{3}{ }^{-}-\mathrm{N}\right]_{i}-\left[\mathrm{NO}_{3}{ }^{-}-\mathrm{N}\right]_{f}}{\left[\mathrm{NO}_{3}{ }^{-}-\mathrm{N}\right]_{i}} \times 100 \\
& R_{\mathrm{NO}_{2}-}(\%)=\frac{\left[\mathrm{NO}_{2}{ }^{-}-\mathrm{N}\right]_{i}-\left[\mathrm{NO}_{2}{ }^{-}-\mathrm{N}\right]_{f}}{\left[\mathrm{NO}^{-}-\mathrm{N}\right]_{i}} \times 100 \\
& R_{\mathrm{NH}_{4}+}(\%)=\frac{\left[\mathrm{NH}_{4}{ }^{+}-\mathrm{N}_{i}-\left[\mathrm{NH}_{4}{ }^{+}-\mathrm{N}\right]_{f}\right.}{\left[\mathrm{NH}_{4}-\mathrm{N}\right]_{i}} \times 100 \\
& R_{\mathrm{N}}(\%)=\frac{\left[\mathrm{NO}_{3}{ }^{-}-\mathrm{N}\right]_{i}+\left[\mathrm{NO}_{2}{ }^{-}-\mathrm{N}\right]_{i}+\left[\mathrm{NH}_{4}{ }^{-}-\mathrm{N}\right]_{i}-\left[\mathrm{NO}_{3}{ }^{-}-\mathrm{N}\right]_{f}-\left[\mathrm{NO}_{2}{ }^{-}-\mathrm{N}\right]_{f}-\left[\mathrm{NH}_{4}{ }^{-}-\mathrm{N}\right]_{f}}{\left[\mathrm{NO}_{3}{ }^{-}-\mathrm{N}\right]_{i}+\left[\mathrm{NO}_{2}{ }^{-}-\mathrm{N}\right]_{i}+\left[\mathrm{NH}_{4}{ }^{+}-\mathrm{N}\right]_{i}} \times 100
\end{aligned}
$$

In this study, the amounts of biological assimilation, organic nitrogen, gaseous nitrogen and adsorbed on bio-minerals were not measured. Accordingly, the nitrogen removal efficiency was calculated only based on measured values of nitrate, nitrite, and ammonium in aqueous solutions.

\section{Results}

The nitrogen removal efficiencies in single nitrate $\left(\mathrm{NO}_{3}{ }^{-}-\mathrm{N}\right)$ reactors and mixed nitrogen $\left(\mathrm{NO}_{3}{ }^{-}-\mathrm{N}+\mathrm{NO}_{2}{ }^{-}-\mathrm{N}+\mathrm{NH}_{4}{ }^{+}-\mathrm{N}\right)$ reactors were evaluated using bacteria (Bacillus cereus strain 146; BC) only, bio-minerals (bio-FeS; BF and bio-Pd-FeS; BPF) only, and the combination of bacteria (Bacillus cereus strain 146; BC) + bio-minerals (bio-FeS; BF and bio-Pd-FeS; BPF) under aerobic conditions.

\subsection{The Aerobic Nitrogen Removal Efficiency in a Single Nitrate $\left(\mathrm{NO}_{3}{ }^{-}-\mathrm{N}\right)$ vs. a Mixed Nitrogen} $\left(\mathrm{NO}_{3}{ }^{-}-\mathrm{N}+\mathrm{NO}_{2}{ }^{-}-\mathrm{N}+\mathrm{NH}_{4}{ }^{+}-\mathrm{N}\right)$ Reactor

\subsubsection{BC (Bacillus cereus Strain 146)}

BC (Bacillus cereus strain 146) in a single nitrate reactor decreased less than $10 \%$ of nitrate $\left(\mathrm{NO}_{3}{ }^{-}{ }^{-} \mathrm{N}\right)$ without production of nitrite $\left(\mathrm{NO}_{2}{ }^{-}-\mathrm{N}\right)$ and ammonium $\left(\mathrm{NH}_{4}{ }^{+}-\mathrm{N}\right)$ for a 5-day incubation time (Figure 1a). BC in a mixed nitrogen $\left(\mathrm{NO}_{3}{ }^{-}-\mathrm{N}+\mathrm{NO}_{2}{ }^{-}-\mathrm{N}+\mathrm{NH}_{4}{ }^{+}-\mathrm{N}\right)$ reactor removed $45 \%$ of nitrite and $100 \%$ of ammonium, but $10 \%$ of nitrate increased (Figure $1 \mathrm{~b}$ ). The nitrogen removal efficiency of BC was $10 \%$ in a single nitrate reactor and $45 \%$ in a mixed reactor. BC showed the preferential removal efficiency of ammonium compared to nitrate and nitrite. As shown in the photo of Figure $1 \mathrm{~b}$, the turbidity development of post BC in a mixed nitrogen reactor was observed and possibly correlated to microbial growth coupled with nitrification or/and denitrification compared to $B C$ in a single nitrate reactor which seemed to give no turbidity as observed in the photo of Figure 1a.

\subsubsection{Bio-minerals: BF (Bio-FeS) and BPF (Bio-Pd-FeS)}

The aerobic nitrogen removal efficiency of bio-minerals was examined in both a single nitrate reactor and a mixed nitrogen reactor for 5-day. BF showed $8 \%$ nitrate removal without nitrite and ammonium produced in a single nitrate reactor (the open symbols, Figure 1c) and 5\% of nitrate and $20 \%$ of ammonium were removed with no change of nitrite concentration in a mixed nitrogen reactor (the open symbols, Figure 1d). The aerobic nitrogen removal efficiency of BF was $8 \%$ in both a single nitrate reactor and a mixed nitrogen reactor. BPF removed $28 \%$ of nitrate without nitrite and ammonium produced in a single nitrate reactor (the closed symbols, Figure $1 \mathrm{c}$ ) and 5\%, $0 \%$ and $10 \%$ of nitrate, nitrite, and ammonium were removed in a mixed nitrogen reactor (the closed symbols, Figure 1d). The aerobic nitrogen removal efficiency of BPF was $28 \%$ in a single nitrate reactor and $5 \%$ in a mixed nitrogen reactor. 
3.1.3. BC + BF (Bacillus cereus Strain $146+$ Bio-FeS) and BC + BPF (Bacillus cereus Strain $146+$ Bio-Pd-FeS)

$\mathrm{BC}+\mathrm{BF}$ removed $42 \%$ of nitrate without production of nitrite and ammonium in a single nitrate reactor (the open symbols, Figure 1e). On the other hand, 55\% of nitrite and 40\% of ammonium were removed but $5 \%$ of nitrate was produced by $\mathrm{BC}+\mathrm{BF}$ in a mixed nitrogen reactor (the open symbols, Figure $1 \mathrm{f}$ ).
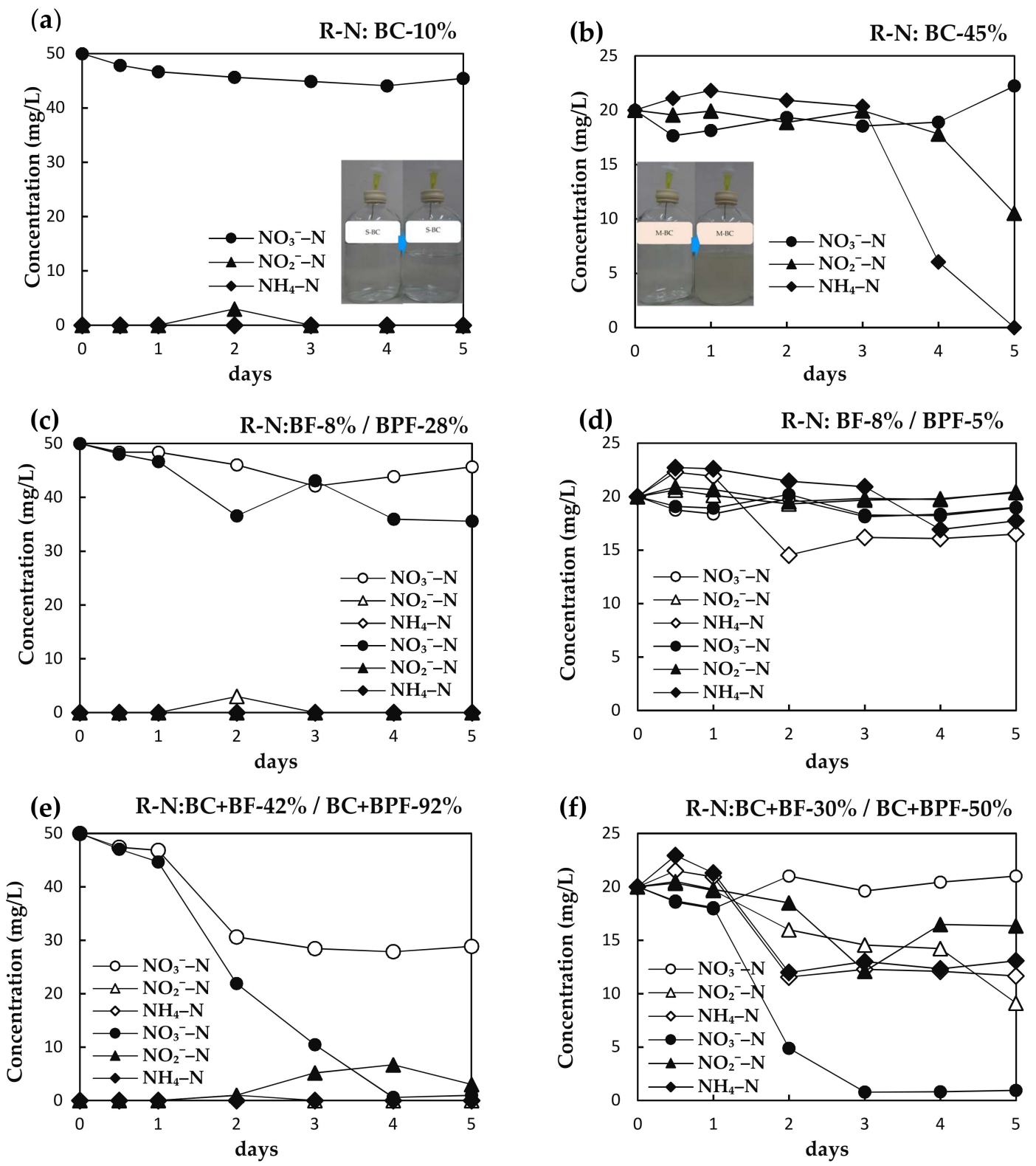

Figure 1. The aerobic nitrogen removal efficiency: (a) BC in a single nitrate reactor; (b) BC in a mixed nitrogen reactor; (c) BF; the open symbols and BPF; the closed symbols in a single nitrate reactor; (d) BF; the open symbols and BPF; the closed symbols in a mixed nitrogen reactor; (e) BC + BF; the open symbols and $\mathrm{BC}+\mathrm{BPF}$; the closed symbols in a single nitrate reactor; (f) $\mathrm{BC}+\mathrm{BF}$; the open symbols and $\mathrm{BC}+\mathrm{BPF}$; the closed symbols in a mixed nitrogen reactors.

The nitrogen removal efficiency of $\mathrm{BC}+\mathrm{BF}$ was $42 \%$ in a single nitrate reactor and $30 \%$ in a mixed nitrogen reactor. $\mathrm{BC}+\mathrm{BPF}$ removed $98 \%$ of nitrate with $6 \%$ and $0 \%$ of nitrite and ammonium produced in a single nitrate reactor (the closed symbols, Figure 1e) and 95\%, 20\%, and 35\% of nitrate, nitrite, and ammonium were removed respectively in a mixed nitrogen reactor (the closed symbols, Figure 1f). 
The nitrogen removal efficiency of $\mathrm{BC}+\mathrm{BPF}$ was $92 \%$ in a single nitrate reactor and $50 \%$ in a mixed nitrogen reactor.

\subsection{Redox Potential and $p H$ Changes}

Redox potential and $\mathrm{pH}$ values of the samples were measured on a daily basis. The decrease of $\mathrm{pH}$ appeared approximately between 1.22 1.24 order downward in BC + BF (the open circle symbols, Figure 2e) and 1.66 1.77 order downward in BC + BPF (the closed circle symbols, Figure 2e), while no significant changes of BC (Figure 2a,b), BF (the open circle symbols, Figure 2c,d), and BPF (the closed symbols, Figure $2 \mathrm{c}, \mathrm{d}$ ) both in single nitrate reactors and mixed nitrogen reactors. Most changes in Eh initiated from the oxidizing conditions (ca. $330 \mathrm{mV}$ ), passed through the reducing conditions and ended at relatively oxidizing conditions. In Figure $2 a, b$, the BC-single nitrate reactor showed minor changes of initiating at $334 \mathrm{mV}$, passing at $158 \mathrm{mV}$ (3-day), and ending $314 \mathrm{mV}$ (5-day) and the BC-mixed nitrogen reactor changed from $332 \mathrm{mV}$ (0-day) through $97 \mathrm{mV}$ (4-day) to $107 \mathrm{mV}$ (5-day). Except for the BC in single nitrate reactor, the changes in the solution Eh of the rest of sets both in single nitrate reactors and mixed nitrogen reactors dropped sharply to ca. 334 to $28 \mathrm{mV}(\mathrm{BF}), 18 \mathrm{mV}(\mathrm{BPF})$, and $-21 \mathrm{mV}, 5 \mathrm{mV}(\mathrm{BC}+\mathrm{BPF})$ within $24 \mathrm{~h}$ and ended at $305 \mathrm{mV}(\mathrm{BF}), 88 \mathrm{mV}(\mathrm{BPF}), 62 \mathrm{mV}(\mathrm{BC}+\mathrm{BF})$, $138 \mathrm{mV}(\mathrm{BC}+\mathrm{BPF})$ in 5 days (the rhombus symbols, Figure 2c,e). Also the changes in Eh of the mixed nitrogen reactors tended to be similarly initiated from $332 \mathrm{mV}$ and dropped to $-21 \mathrm{mV}(\mathrm{BF}), 32 \mathrm{mV}$ $(\mathrm{BPF}),-31 \mathrm{mV}(\mathrm{BC}+\mathrm{BF})$, and $36 \mathrm{mV}(\mathrm{BC}+\mathrm{BPF})$ within $24 \mathrm{~h}$ and ended at $104 \mathrm{mV}(\mathrm{BF}), 126 \mathrm{mV}(\mathrm{BPF})$, $176 \mathrm{mV}(\mathrm{BC}+\mathrm{BF})$, and $224 \mathrm{mV}(\mathrm{BC}+\mathrm{BPF})$ for 5 days (the rhombus symbols, Figure $2 \mathrm{~d}, \mathrm{f})$. The results showed that concurrent changes of Eh-pH could provide adequate and effective conditions for the nitrogen removal, for instance, in $\mathrm{BC}+\mathrm{BF}$ and $\mathrm{BC}+\mathrm{BPF}$ reactors.
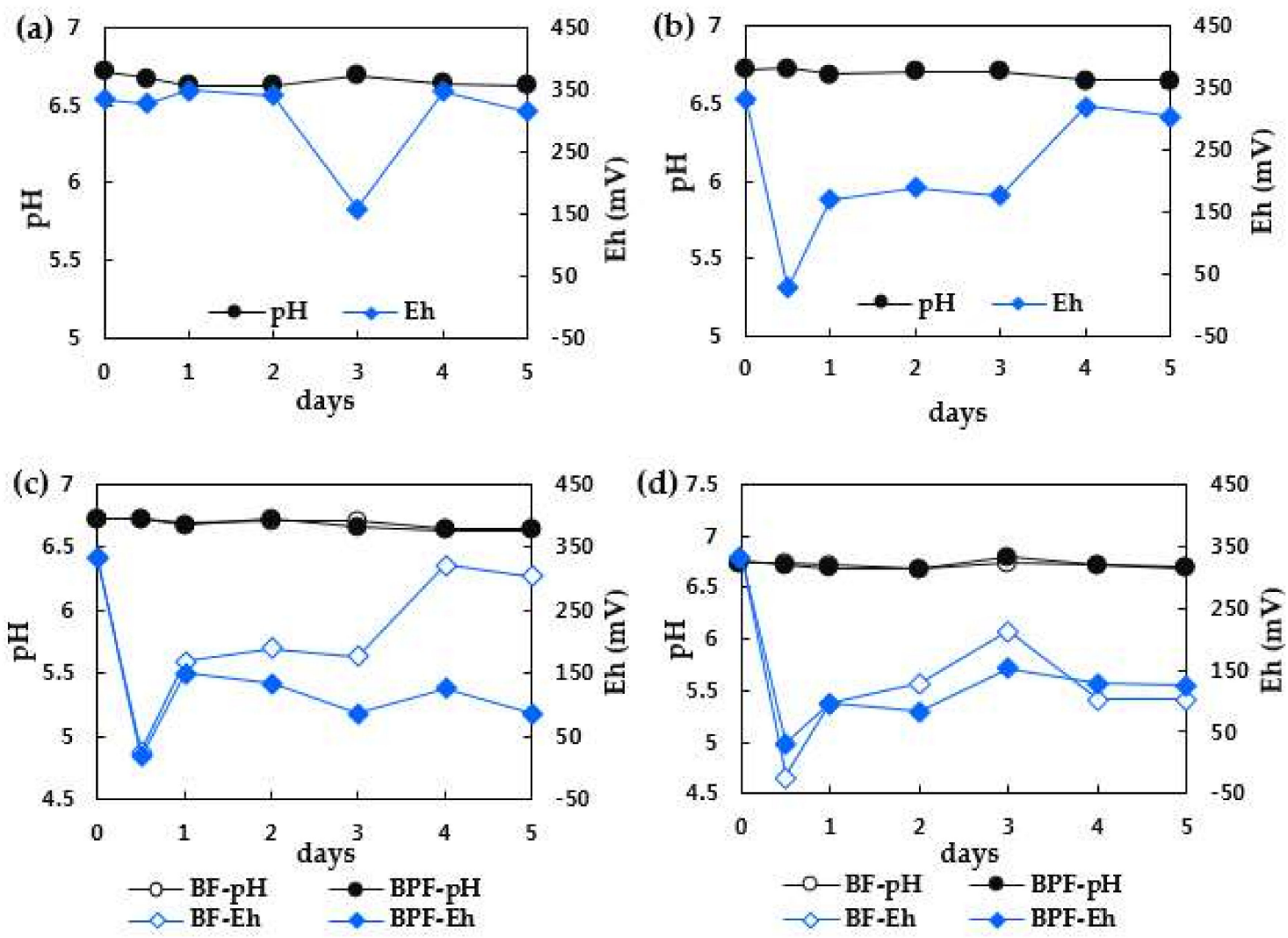

Figure 2. Cont. 

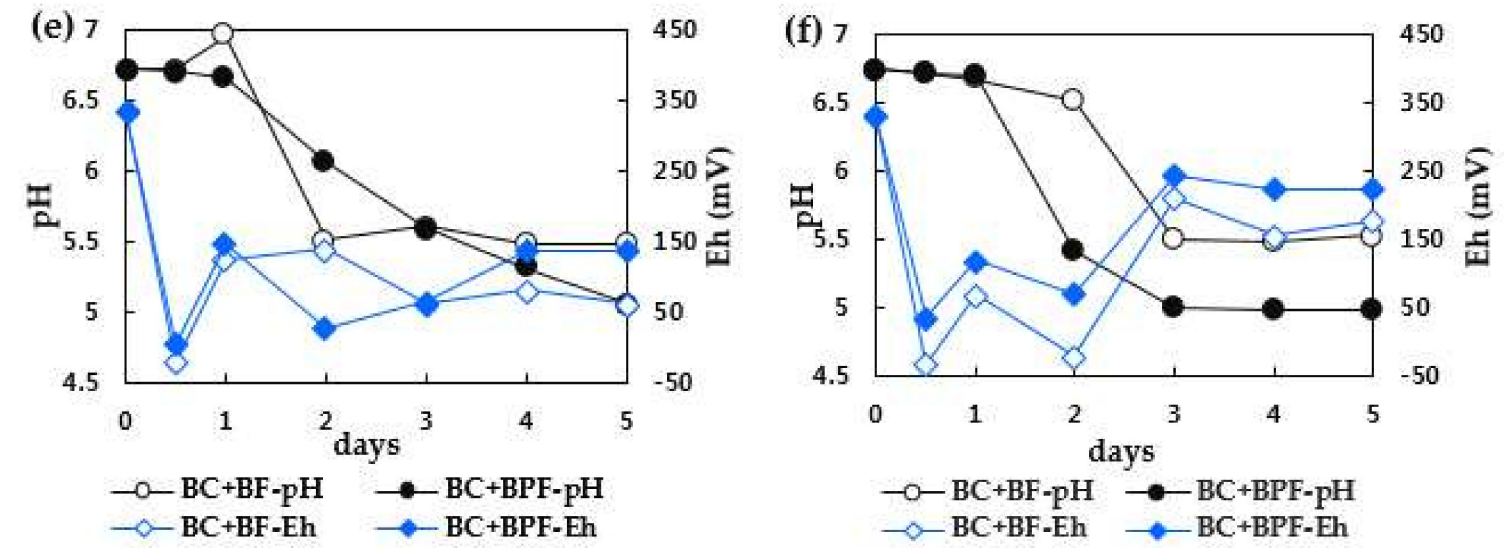

Figure 2. Changes in $\mathrm{pH}$ of (a) $\mathrm{BC}$; (c) BF; open circle, BPF; closed circle (e) $\mathrm{BC}+\mathrm{BF}$; open circle, $\mathrm{BC}+\mathrm{BPF}$; closed circle in a single nitrate $\left(\mathrm{NO}_{3}{ }^{-} \mathrm{N}\right)$ reactors and $(\mathbf{b}) \mathrm{BC} ;(\mathrm{d}) \mathrm{BF}$; open circle, BPF; closed circle (f) $\mathrm{BC}+\mathrm{BF}$; open circle, $\mathrm{BC}+\mathrm{BPF}$; closed circle in mixed nitrogen $\left(\mathrm{NO}_{3}-\mathrm{N}+\mathrm{NO}_{2}-\mathrm{N}+\mathrm{NH}_{4}{ }^{+}-\mathrm{N}\right)$ reactors. Eh of (a) $\mathrm{BC}$; (c) $\mathrm{BF}$; open rhombus, $\mathrm{BPF}$; closed rhombus (e) $\mathrm{BC}+\mathrm{BF}$; open rhombus, $\mathrm{BC}+\mathrm{BPF}$; closed rhombus in a single nitrate $\left(\mathrm{NO}_{3}{ }^{-}-\mathrm{N}\right)$ reactors and $(\mathbf{b}) \mathrm{BC}$; (d) BF; open rhombus, $\mathrm{BPF}$; closed rhombus (f) $\mathrm{BC}+\mathrm{BF}$; open rhombus, $\mathrm{BC}+\mathrm{BPF}$; closed rhombus in mixed nitrogen $\left(\mathrm{NO}_{3}-\mathrm{N}+\mathrm{NO}_{2}-\mathrm{N}+\mathrm{NH}_{4}{ }^{+}-\mathrm{N}\right)$ reactors.

\subsection{The Amount of Produced $\mathrm{SO}_{4}{ }^{2-}$ in the Nitrogen Removal Reaction}

Since BF and BPF are ferrous and sulfide-based catalysts, we might notice that the amount of produced sulfate $\left(\mathrm{SO}_{4}{ }^{2-}\right)$ could be regarded as a contaminant in case of excessive release in groundwater. In this study, the amounts of sulfate $\left(\mathrm{SO}_{4}{ }^{2-}\right)$ produced in order were $\mathrm{BC}<\mathrm{BC}+\mathrm{BPF}<\mathrm{BC}+\mathrm{BF}<\mathrm{BF}<\mathrm{BPF}$ in single nitrate reactors and $\mathrm{BC}<\mathrm{BC}+\mathrm{BPF}<\mathrm{BPF}=\mathrm{BC}+\mathrm{BF}<\mathrm{BF}$ in mixed nitrogen reactors. In particular, $\mathrm{BPF}, \mathrm{BC}+\mathrm{BF}$, and $\mathrm{BC}+\mathrm{BPF}$ in single nitrate reactors showed about two-fold less production of sulfate than those in mixed nitrogen reactors (Figure 3).

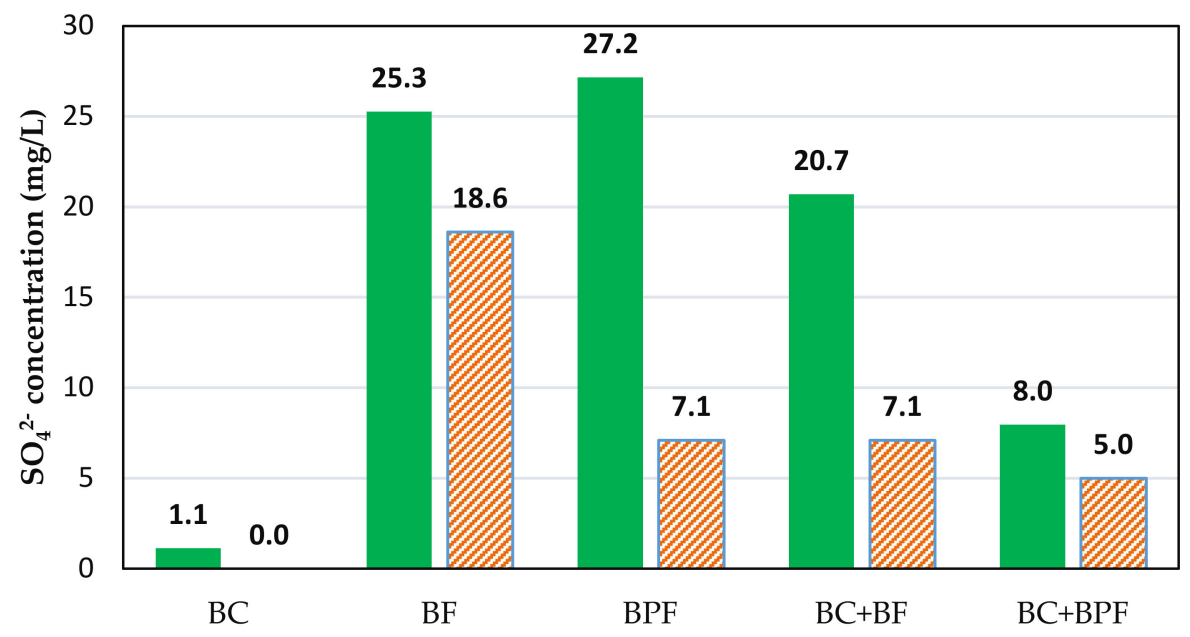

- Single nitrate reactor $\square$ Mixed nitrogen reactor

Figure 3. The amount of produced $\mathrm{SO}_{4}{ }^{2-}$ concentrations after 5 days of incubation compared with single nitrate reactors (greenish filled) and mixed nitrogen reactors (reddish diagonal pattern).

\subsection{The Transformation of Bio-Minerals (BF and BPF) Pre-and Post-Reactions}

In Figure 4, changes in color of BF and BC + BF in single nitrate reactors are shown, which transformed from black to yellowish. BF was identified as a composite of nano-sized crystalline and amorphous FeS [20], 
but after the reactions of amorphous ferric oxides were observed. In terms of color changes, $\mathrm{BPF}$ and $\mathrm{BC}+\mathrm{BPF}$ maintained a dark gray in color and XRD patterns indicated crystalline ferric oxides including goethite.
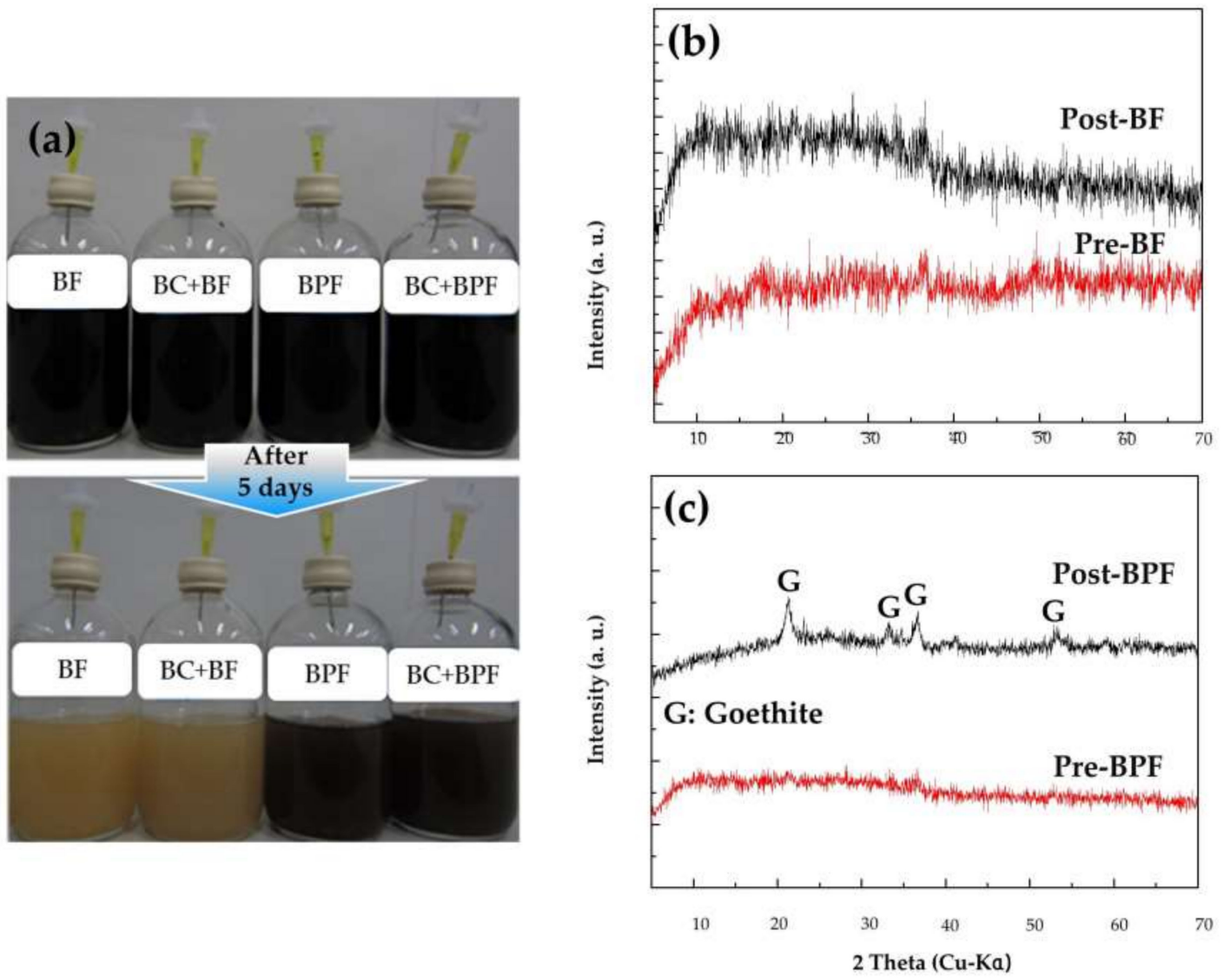

Figure 4. Changes in colors: (a, upper) pre-BF, $\mathrm{BC}+\mathrm{BF}, \mathrm{BPF}$ and $\mathrm{BC}+\mathrm{BPF}$ in single nitrate reactors and (a, lower) Post-BF, BC $+\mathrm{BF}, \mathrm{BPF}$, and $\mathrm{BC}+\mathrm{BPF}$ in single nitrate reactors. XRD patterns of $(\mathbf{b})$ pre- and post-BF and (c) pre- and post-BPF.

In Figure 5a,b, SEM images of BF before the reaction (Figure $5 \mathrm{a}$ ) and $\mathrm{BC}+\mathrm{BF}$ after the reaction with nitrate (Figure $5 b$ ) for 5 -day presented morphological and chemical changes of BF. BF before the reaction appeared to be 100 200 $\mathrm{nm}$ in size and with petal-like aggregates in shape (Figure 5a). The major components of BF before the reaction consisted of Fe (69 wt \%), S (18 wt \%), C (9wt \%), and $\mathrm{O}(3 \mathrm{wt} \%$ ) (Figure $5 \mathrm{a}, \mathrm{c})$. On the other hand, morphological changes of $\mathrm{BC}+\mathrm{BF}$ after the reaction with nitrate were observed; the predominant presence of ca. 3- $\mu \mathrm{m}$ rod-shaped microorganisms and irregularly shaped aggregates (Figure $5 b, d$ ). Also, compared to pre-BF, chemical components and portions of post-BC + BF appeared in order of $\mathrm{O}(38.7 \mathrm{wt} \%), \mathrm{C}(26.9 \mathrm{wt} \%), \mathrm{Fe}(23.7 \mathrm{wt} \%), \mathrm{N}(6.9 \mathrm{wt} \%)$, $\mathrm{K}(1.7 \mathrm{wt} \%), \mathrm{S}(1.1 \mathrm{wt} \%)$, and $\mathrm{Al}(1 \mathrm{wt} \%)$. As a result, the changes in the chemical portion of post-BF might reflect the increase of $\mathrm{SO}_{4}{ }^{2-}$ and depletion of $\mathrm{S}^{2-}$ during the reactions. Also, we noticed a multi-fold increase of $\mathrm{O}, \mathrm{C}$, and $\mathrm{N}$ might associate with increasing the population of microorganisms in the reactor.

As shown in Figure 6, SEM images of BPF before the reaction (Figure 6a) and post-BC + BPF with nitrate (Figure $6 \mathrm{~b}$ ) are presented. Morphological and chemical characteristics of pre-BPF appeared as mostly 100 150-nm rod-shaped aggregates. The major components of pre-BPF consisted of Fe (63 wt \%), $\mathrm{O}(15 \mathrm{wt} \%), \mathrm{S}(7.5 \mathrm{wt} \%), \mathrm{Pd}(7 \mathrm{wt} \%)$, and C (6.5 wt \%) (Figure 6a, inner circle and 6c). Morphological changes of post-BC + BPF appeared as BPF aggregates covered with microorganisms and their byproducts with apparent morphological changes in size and shape (Figure 6b). Also, compared to pre-BPF, chemical components and portions of post-BC + BPF appeared in the order of $\mathrm{O}(36 \mathrm{wt} \%), \mathrm{Fe}(27.5 \mathrm{wt} \%), \mathrm{C}(25 \mathrm{wt} \%)$, 
$\mathrm{N}(6.9 \mathrm{wt} \%), \mathrm{S}(3 \mathrm{wt} \%)$, Pd (3 wt \%), and Al (1 wt \%) (Figure 6b, inner circle, and d). These results from SEM-EDS analysis of pre- and post-BC + BPF implicated the oxidation of BPF coupled with changes in the chemical portion of post-BC $+\mathrm{BPF}$.
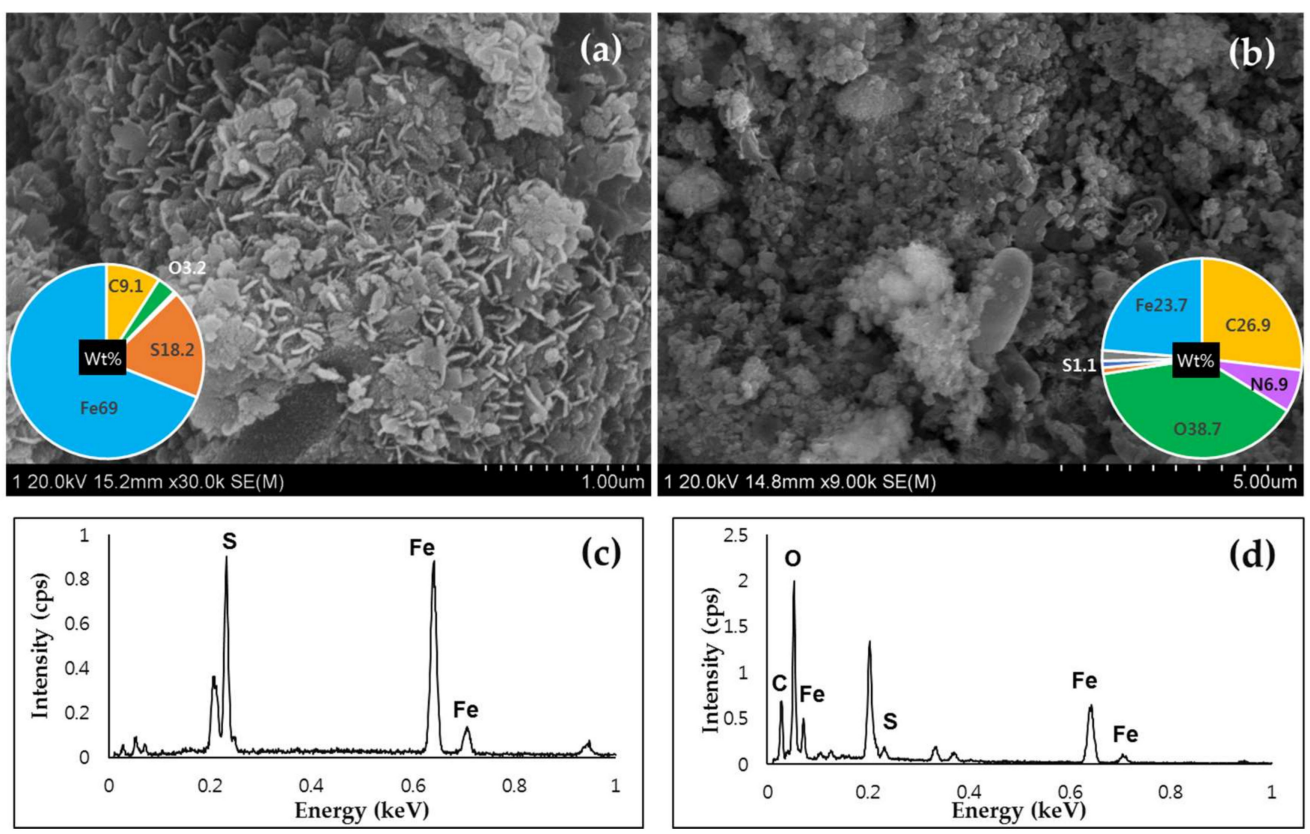

Figure 5. SEM images of (a) BF before reaction with a pie graph indicating elemental weight percentage in relation to (c) EDS spectra and (b) BC $+\mathrm{BF}$ after reaction with a pie graphs indicating elemental weight percentage in relation to (d) EDS spectra.
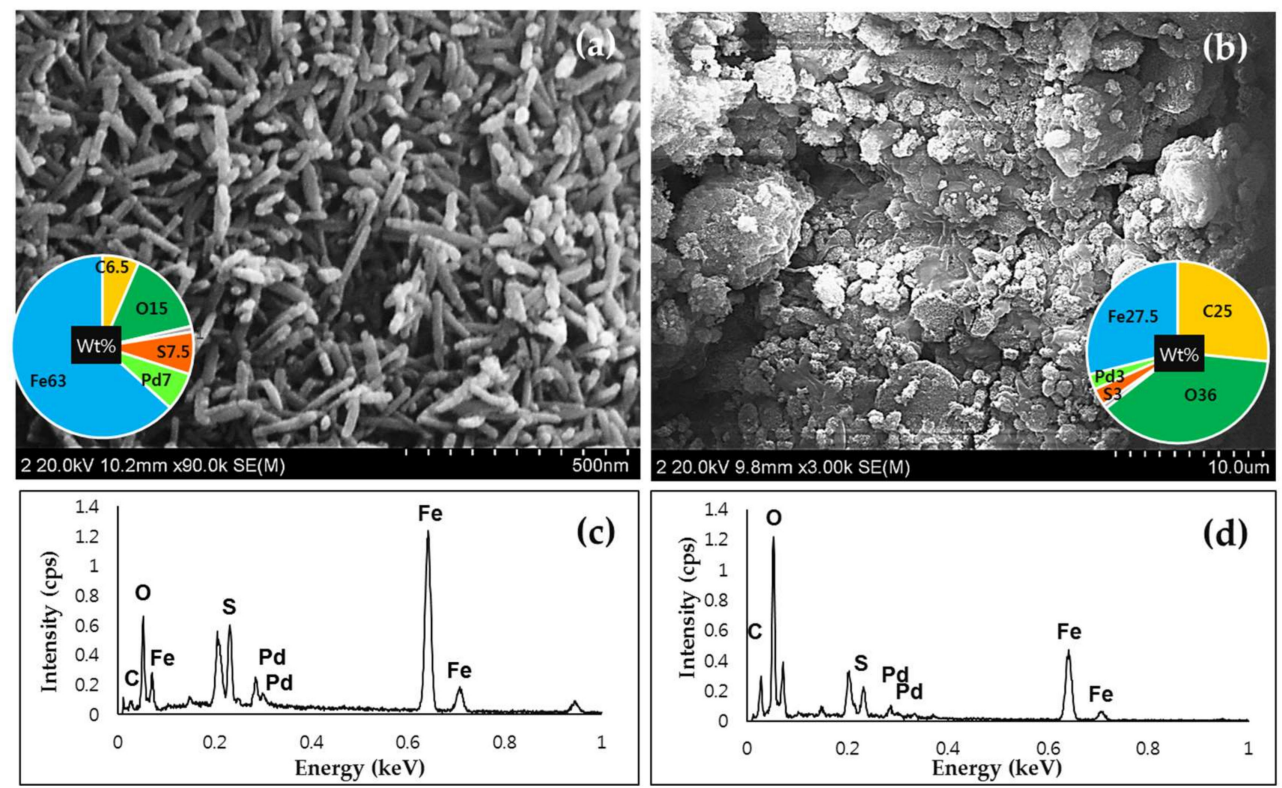

Figure 6. SEM images of (a) BPF before reaction with a pie graph indicating elemental weight percentage in relation to (c) EDS spectra and (b) BC + BPF after reaction with a pie graph indicating elemental weight percentage in relation to (d) EDS spectra.

\section{Discussion}

In this study, the aerobic nitrogen removal efficiency of BC (Bacillus cereus strain 146) showed ca. $10 \%$ in a single nitrate and $45 \%$ in a mixed nitrogen reactor for 5 days. Generally, Bacillus sp. as 
heterotrophic nitrifying bacteria has been proved to perform the capability of oxidation of ammonium into nitrite followed by nitrite to nitrate within hours coupled with microbial growth through the utilization of external carbon sources from earlier findings [6,7,22,23]. It closely matched the result of Bacillus cereus strain 146 in a mixed nitrogen reactor which removed all the ammonium with microbial growth through turbidity development in the reactor (Figure 1b-inner photo). This result also indicated that low microbial growth might be responsible for low nitrogen removal efficiency in a single nitrate reactor (Figure 1a). In this study, Bacillus cereus 146 was observed inactive in a single nitrate reactor, but active in ammonium removal reaction in mixed nitrogen reactor in 5-day incubation times. Presumably, the nitrification process could be a dominant reaction in the mixed nitrogen reactor in aerobic conditions.

The removal of nitrogen compounds requires not only electron donors but also catalysts. BF and BPF without catalytic supports removed ca. $10 \%$ and $28 \%$ nitrogen compounds in single nitrate reactors, respectively, under an aerobic condition. Previous studies showed that natural pyrite-based autotrophic treatment removed over $95 \%$ nitrogen with less than $10 \%$ ammonium produced, which was similar to our removal rate, but production of sulfate was about $650 \mathrm{mg} / \mathrm{L}$ for 5 days compared to less than $30 \mathrm{mg} / \mathrm{L}$ in this study [18]. In relation to the aqueous $\mathrm{pH}$ condition, chemically synthesized FeS reduced nitrate and nitrite to ammonia/ammonium under high temperature above $70{ }^{\circ} \mathrm{C}[24]$. These reactions induced reducing and alkaline conditions through $\mathrm{Fe}^{2+}$ and $\mathrm{S}^{2-}$ donating electrons to $\mathrm{NO}_{2}{ }^{-}$and NO. In this study, bio-FeS also did not perform well under a neutral aerobic condition at $25{ }^{\circ} \mathrm{C}$, but bio-Pd-FeS showed $28 \%$ of nitrogen removal efficiency. The addition of Pd in bio-minerals might contribute to increasing the efficiency of nitrogen removal. In the previous findings, the catalytic effects of $\mathrm{Pd}$ were reported as the most effective metal for the reduction of nitrite and nitrate with co-catalysts under acidic conditions with $\mathrm{pH}$ ranged from 5.5 to 6 [25].

As $\mathrm{pH}$ indicates the concentration of $\mathrm{H}^{+}$in a solution, redox potential shows the activity of electrons. The combination of bacteria (BC) and bio-minerals (BF/BPF) enhanced the efficiency of nitrogen removal. The effectiveness of nitrate removal appeared to be $42 \%$ by $\mathrm{BC}+\mathrm{BF}$ and $98 \%$ by $\mathrm{BC}+\mathrm{BPF}$ with minor production of ammonium in single nitrate reactors. The effect of $\mathrm{pH}$ on nitrate and nitrite reduction led to an increased reduction rate as the $\mathrm{pH}$ approached 6 [26,27] which showed a similar tendency in this study. Changes in the $\mathrm{pH}$ of $\mathrm{BC}+\mathrm{BF}$ (the open circle symbols, Figure 2e,f) and $\mathrm{BC}+\mathrm{BPF}$ (the closed circle symbols, Figure 2e,f) in a single nitrate and mixed nitrogen reactors ranged between 1.2 and 1.7 orders toward acidic conditions. However, the optimal $\mathrm{pH}$ and Eh conditions for nitrification and denitrification might be different. For instance, in a previous finding, the optimal $\mathrm{pH}$ for the ammonium removal was ca. $\mathrm{pH} 8$ [24]. In this study, compared to changes in $\mathrm{pH}-\mathrm{Eh}$ of $\mathrm{BC}$ in a single nitrate reactor appeared insignificant both, in which of $\mathrm{BC}$ in a mixed nitrogen reactor the solution Eh transformed from $332 \mathrm{mV}$ to $97 \mathrm{mV}$ for 4-day and ended to $107 \mathrm{mV}$ for 5-day, whereas the solution $\mathrm{pH}$ did not change (Figure $2 \mathrm{~b}$ ). Accordingly, BC in the redox condition might be favorable to the oxidation of ammonium or the reduction to dinitrogen. In Figure 7, the changes in aqueous Eh-pH conditions tended to transform toward the acidic and reducing zones and it is closely related to the nitrogen removal efficiency as dominant indicators. For higher nitrogen removal efficiency, the acidic and reducing condition could be a prerequisite. A dotted reddish circle (Figure 7) could be interpreted as geochemically $\mathrm{N}_{2}$ or/and $\mathrm{NH}_{4}{ }^{+}$stable zones where only the combination of bacteria and bio-minerals (bio-FeS and bio-Pd-FeS) formed. Since the measured amount of $\mathrm{NH}_{4}{ }^{+}$appeared minor in this study, the production of $\mathrm{N}_{2}$ could be the most possible reaction. Also, Luther III et al. studied sulfide oxidation by oxygen and suggested that aerobic sulfide oxidation rates are three orders of magnitude higher than abiotic rates [28]. These findings closely support our results that the combination of bacteria and bio-(Pd)-FeS improved aerobic nitrogen removal efficiency. In particular, one of the proton- and electron-producing reactions leading to acidic and reducing conditions could be from nitrification, oxidation of organic carbon, and oxidation of bio-FeS with microbial activities. 


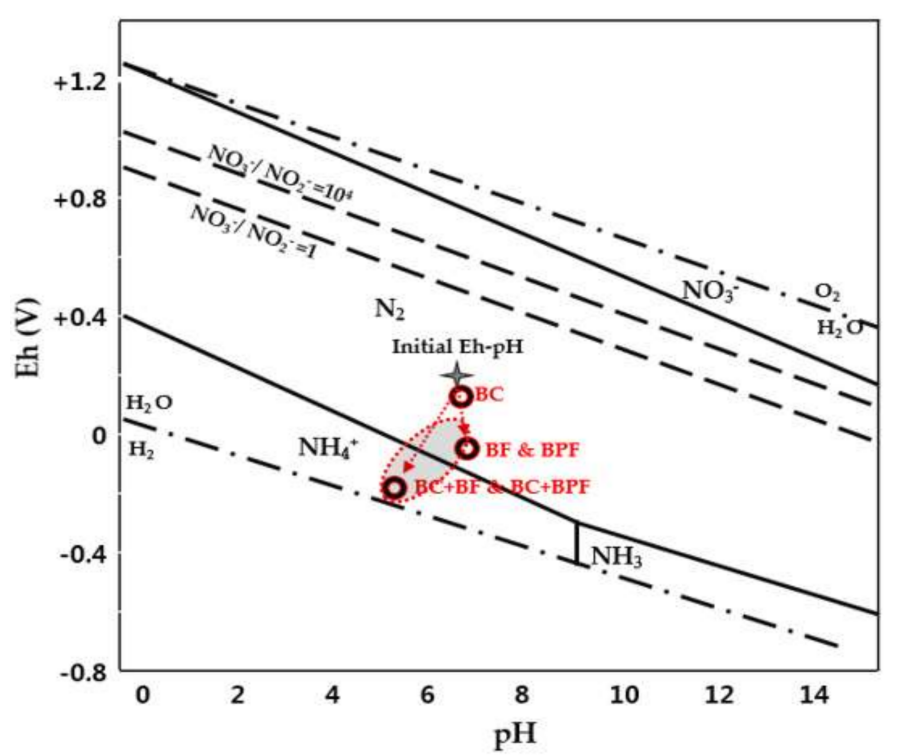

Figure 7. Changes in Eh-pH of $\mathrm{BC}, \mathrm{BF}, \mathrm{BPF}, \mathrm{BC}+\mathrm{BF}$, and $\mathrm{BC}+\mathrm{BPF}$ in single nitrate reactors plotted on the diagram edited by Eby, G.N. [29].

\section{Conclusions}

In this study, an integrated bio-minerals + bacteria were shown to enhance the efficiency of aerobic nitrogen removal at a circumneutral condition. Bacillus cereus strain 146 showed the highest capability of oxidizing ammonium in a mixed nitrogen reactor than reducing nitrate in a single nitrate reactor under an aerobic condition within 5 days. In bio-minerals, BPF was shown to be more capable to reduce nitrogen contaminants than BF. The BC + BPF system showed the best efficiency of nitrogen removal with low production of nitrite and ammonium. Changes in $\mathrm{pH}$-Eh conditions through providing high density of electrons and protons by bio-minerals, catalytic effects of $\mathrm{Pd}$, and enzymatic effects of $\mathrm{BC}$ performed synergistically to enhance the efficiency of aerobic nitrogen removal. Since iron and sulfur are regarded as easily accessible and reusable by simply blocking oxygen, these results could provide an efficient, economical, and eco-friendly sustainable denitrification system under an aerobic condition.

Author Contributions: H.S. designed and performed the experiments, collected, analyzed, and interpreted data and wrote manuscript; Y.R. conceived and initiated the original idea, provided the critical feedback, and acted as a corresponding author.

Acknowledgments: This research was supported by GAIA project (RE201402059) of the ministry of Environment and National Research Foundation (NRF-2016R1D1A1A09917588) of the R. Korea. We appreciated to Y.C. at KBSI-Gwangju Branch for SEM-EDS, Y.K. at CCRF in Chonnam National University-Yeosu Branch for IC analysis, and K.J. at CCRF in Chonnam National University -Gwangju Branch for XRD analysis.

Conflicts of Interest: The authors declare no conflict of interest.

\section{References}

1. World Health Organization. Guidelines for Drinking-Water Quality, 4th ed.; World Health Organization: Geneva, Switzerland, 2011; pp. 398-403.

2. International Groundwater Resources Assessment Centre. Available online: https://un-igrac.org/resource/ global-assessment-nitrate-contamination-groundwater (accessed on 17 January 2018).

3. Elyanow, D.; Persechino, J. Advances in Nitrate Removal. Available online: https:/ / www.sueswatertechnologies.com (accessed on 3 February 2018).

4. Naik, S.; Setty, Y. Biological denitrification of wastewater-A mini review on carbon source. In Proceedings of the International Conference on Chemical, Environmental Science and Engineering, Pattaya, Thailand, 28-29 July 2012. 
5. Lee, H.W.; Park, Y.K.; Choi, E.; Lee, J.W. Bacterial community and biological nitrate removal: Comparisons of autotrophic and heterophic reactors for denitrification with raw sewage. J. Microbial. Biotechnol. 2008, 18, 1826-1835. [CrossRef]

6. Zhao, B.; He, Y.L.; Zhang, X.F. Nitrogen removal capability through simultaneous heterotrophic nitrification and aerobic denitrification by Bacillus sp. LY. Environ. Technol. 2010, 31, 409-416. [CrossRef] [PubMed]

7. Kim, J.K.; Park, K.J.; Cho, K.S.; Nam, S.W.; Park, T.J.; Bajpai, R. Aerobic nitrification-denitrification by heterotrophic Bacillus strains. Bioresource Technol. 2005, 96, 1897-1906. [CrossRef] [PubMed]

8. Zhu, I.; Getting, T. A review of nitrate reduction using inorganic materials. Environ. Technol. Rev. 2012, 1, 46-58. [CrossRef]

9. Su, C.; Puls, R. Nitrate reduction by zerovalent iron: Effects of formate, oxalate, citrate, chloride, sulfate, borate, and phosphate. Environ. Sci. Technol. 2004, 38, 2715-2720. [CrossRef] [PubMed]

10. Choe, S.; Liljestrand, H.M.; Khim, J. Nitrate reduction by zero-valent iron under different $\mathrm{pH}$ regimes. Appl. Geochem. 2004, 19, 335-342. [CrossRef]

11. Guo, X.; Yang, Z.; Lie, H.; Lv, X.; Tu, Q.; Ren, Q.; Xia, X.; Jing, C. Common oxidants active the reactivity of zero-valent iron (ZVI) and hence remarkably enhance nitrate reduction from water. Sep. Purif. Technol. 2015, 146, 227-234. [CrossRef]

12. Choi, J.; Shin, W.S.; Choi, S.J.; Kim, Y.H. Reductive denitrification using zero-valent iron and bimetallic iron Environ. Technol. 2009, 30, 939-946. [CrossRef]

13. Sun, W.; Li, Q.; Gao, S.; Shang, J.K. Monometallic $\mathrm{Pd} / \mathrm{Fe}_{3} \mathrm{O}_{4}$ catalyst for denitrification of water. Appl. Catal. B Environ. 2012, 125, 1-9. [CrossRef]

14. Jung, J.; Bae, S.; Lee, W. Nitrate reduction by maghemite supported Cu-Pd bimetallic catalyst. Appl. Catal. B Environ. 2012, 127, 148-158. [CrossRef]

15. Ottley, C.J.; Davison, W.; Edmunds, W.M. Chemical catalysis of nitrate reduction by iron (II). Geochim. Cosmochim. Acta 1997, 61, 1819-1828. [CrossRef]

16. Brunet, R.C.; Garcia-Gil, L.J. Sulfide-induced dissimilatory nitrate reduction to ammonia in anaerobic freshwater sediments. FEMS Microbiol. Ecol. 1996, 21, 131-138. [CrossRef]

17. Henderson, A.D.; Demond, A.H. Permeability of iron sulfide (FeS)-based materials for groundwater remediation. Water Res. 2013, 47, 1267-1276. [CrossRef] [PubMed]

18. Pu, J.; Feng, C.; Liu, Y.; Li, R.; Kong, Z.; Chen, N.; Tong, S.; Hao, C.; Liu, Y. Pyrite-based autotrophic denitrification for remediation of nitrate contaminated groundwater. Bioresour. Technol. 2014, 173, 117-123. [CrossRef] [PubMed]

19. Till, B.A.; Weathers, L.J.; Alvarez, P.J.J. Fe (0)-supported autotrophic denitrification. Environ. Sci. Technol. 1998, 32, 634-639. [CrossRef]

20. Seo, H.; Roh, Y. Mixed contaminants removal efficiency using bio-FeS nanoparticles. J. Nanosci. Nanotechnol. 2017, 17, 1-4. [CrossRef] [PubMed]

21. Kalkowski, I.; Conrad, R. Metabolism of nitric oxide in denitrifying Pseudomonas aeruginosa and nitrate-respiring Bacillus cereus. FEMS Microbiol. Lett. 1991, 82, 107-112. [CrossRef]

22. Rout, P.R.; Bhunia, P.; Dash, R.R. Simultaneous removal of nitrogen and phosphate from domestic wastewater using Bacillus cereus GS-5 strain exhibiting heterotrophic nitrification, aerobic denitrification and denitrifying phosphorous removal. Bioresource Technol. 2017, 244, 484-495. [CrossRef] [PubMed]

23. Shin, K.; Cha, D.K. Microbial reduction of nitrate in the presence of nanoscale zero-valent iron. Chemosphere 2008, 72, 257-262. [CrossRef] [PubMed]

24. Gordon, A.D.; Smirnov, A.; Shumlas, S.L.; Singireddy, S.; DeCesare, M.; Schoonen, M.A.A.; Strongin, D.R. Reduction of nitrite and nitrate on nano-dimensioned FeS. Oringins Life Evol. Biosph. 2013, 43, 305-322. [CrossRef] [PubMed]

25. Guy, K.A.; Xu, H.; Yang, J.C.; Werth, C.J.; Shapley, J.R. Catalytic nitrate and nitrite reduction with Pd-Cu/PVP colloids in water: Composition, structure, and reactivity correlations. J. Phys. Chem. C 2009, 113, 8177-8185. [CrossRef]

26. Chirita, P.; Descostes, M.; Schlegel, M.L. Oxidation of FeS by oxygen-bearing acidic solutions. J. Colloid Interf. Sci. 2008, 321, 84-95. [CrossRef] [PubMed]

27. Sheela, B.; Khasim, B.S.; Yellaji, R.O. Simultaneous nitrification and denitrification of ammonical wastewaters using Bacillus species SBI isolated from domestic sewage. IJLBPR 2015, 4, 17-21. [CrossRef] 
28. Luther, G.W., III; Findlay, A.J.; MacDonald, D.J.; Owings, S.M.; Hanson, T.E.; Beinart, R.A.; Girguis, P.R. Thermodynamics and kinetics of sulfide oxidation by oxygen: A look at inorganically controlled reactions and biologically mediated processes in the environment. Front. Microbiol. 2011, 2, 1-9. [CrossRef] [PubMed]

29. Eby, G.N. Principles of Environmental Geochemistry; Waveland Press, Inc.: Long Grove, IL, USA, 2016; pp. 108-109.

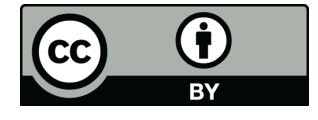

(c) 2018 by the authors. Licensee MDPI, Basel, Switzerland. This article is an open access article distributed under the terms and conditions of the Creative Commons Attribution (CC BY) license (http:/ / creativecommons.org/licenses/by/4.0/). 